\title{
Spatial distribution of Puya coerulea Lindl. in response to abiotic factors and accompanying species in the Río Clarillo National Reserve
}

\section{Distribución espacial de Puya coerulea Lindl. como respuesta a factores abióticos y especies acompañantes en la Reserva Nacional Río Clarillo}

\author{
Milton A. N. Ortuño ${ }^{*}$, Alonso E. Machtig ${ }^{1}$, Martín A. Chacón ${ }^{1}$, Jael Cuzmar ${ }^{1}$ \& Francisco E. \\ FONTÚRBEL ${ }^{2}$
}

1Departamento de Ciencias Ecológicas, Facultad de Ciencias, Universidad de Chile, Santiago, Chile. ${ }^{2}$ Instituto de Biología, Facultad de Ciencias, Pontificia Universidad Católica de Valparaíso, Valparaíso, Chile. *milton.ortuno@ug.uchile.cl

\begin{abstract}
RESUMEN
Puya coerulea presenta una distribución agregada característica, formando densos parches, los cuales están determinados principalmente por la cobertura rocosa más que por otras variables abióticas. Así mismo, la composición de la flora acompañante de $P$. coerulea es significativamente diferente a la composición de plantas donde esta bromeliácea está ausente.
\end{abstract}

Many plant species present a non-random spatial distribution, forming aggregates in response to abiotic (e.g., soil moisture, sunlight incidence) and biotic (e.g., competition, seed dispersal) factors (Nathan \& MullerLandau 2000). This is the case of Puya coerulea Lindl. (Bromeliaceae), a plant species endemic to Chile, distributed from $30^{\circ}$ to $38^{\circ} \mathrm{S}$, corresponding to one of the seven Chilean species within the Puya genus, and comprised within the subgenus Puyopsis (Smith \& Downs 1974). This bromeliad is subdivided into four varieties (Smith 1970) within which we found $P$. coerulea var. coerulea, present at our study area. This variety is distributed from the Valparaiso Region (cerro La Campana, $32^{\circ} 57^{\prime} \mathrm{S}$ ) to the O'Higgins Region (Cachapoal, 33 ${ }^{\circ} 55^{\prime} \mathrm{S}$ ), ranging between 500 and $2000 \mathrm{~m}$ of altitude, and mainly growing in rocky outcrops at semi-arid areas. Examining plant species spatial patterns can provide valuable insights on the underlying ecological processes shaping those patterns (Stoll \& Prati 2001). This is particularly interesting for those species that are usually found forming densely aggregated and discrete distributions. Therefore, the aim of this study was to assess the abiotic factors determining $P$. coerulea spatial distribution.

This study was carried out during October 2017, at the Río Clarillo National Reserve $\left(33^{\circ} 45^{\prime} \mathrm{S} 70^{\circ} 25^{\prime} \mathrm{W}\right)$, located $45 \mathrm{~km}$ from the city of Santiago. We collected data along a $2-\mathrm{km}$ transect (at both sides of the road) with suitable conditions for $P$. coerulea. At this transect, we defined 71 random points separated by $\sim 20 \mathrm{~m}$ from each other. At each sampling point we determined presence or absence of $P$. coerulea and measured the following abiotic variables:
UV radiation (using a Vetus UV340B portable UV-meter, placed horizontally at $1.30 \mathrm{~m}$ above the ground), percentage of rock cover (visually estimated, as the fraction of a $5 \times 5$ $\mathrm{m}$ plot covered by rock), and soil inclination and slope orientation (both measured using a digital inclinometer). At each sampling point we took two measurements, one at each side of the road. Additionally, we registered the accompanying plant species present at each sampling point. Then, we obtained geographical coordinates from each $P$. coerulea cluster (composed by one to five individuals, using a Garmin Map 62s GPS device with error $\leq 5 \mathrm{~m}$ ) found at the study area.

We performed a Mixed-Effects Generalized Linear Model (GLMM) with a binomial error distribution to determine which abiotic variables (included as fixed predictors) explain $P$. coerulea presence or absence; road side was included as a random factor (Zuur et al. 2009). GLMM goodness-of-fit was assessed using a HosmerLemeshow test. Then, we performed an Analysis of Similarities (ANOSIM; using a Bray Curtis similarity metric and 1,000 permutations) to compare plant species composition between sampling points with and without $P$. coerulea. ANOSIM is a nonparametric test aimed to test community composition differences, it is based on similarity matrices and its significance level is calculated using permutations (Clarke 1993). GLMM and ANOSIM analyses were conducted in R 3.5.0 (R Core Development Team 2018) using the packages 'vegan', 'pscl', 'mgcv', 'Ime4', 'ImerTest' and 'pbkrtest'. Finally, we performed point-pattern analysis using the geographic coordinates 
of $P$. coerulea clusters obtained in the field. We used the Programita software (freely available at www.programita. org) to perform a spatial aggregation analysis using the $\mathrm{g}(\mathrm{r})$ function in an irregular area defined by the entire area of rocky outcrops present at the study area (i.e., P. coerulea suitable habitat). To evaluate the significance of the observed pattern, we constructed a null model upon 999 simulations under a model of complete spatial randomness (Wiegand \& Moloney 2004, 2014). To improve the visualization of the spatial aggregation pattern obtained, the values obtained were divided by the expected value and transformed to $\log (\mathrm{x}+1)$. Original data and $\mathrm{R}$ scripts associated to this submission is available from the figshare repository: https:// doi.org $/ 10.6084 / \mathrm{m} 9$.figshare. 7045094
The presence of $P$. coerulea at the study area was largely determined by the percentage of rock cover (Table 1 ), indicating that this factor is the main determinant of its presence over the other environmental factors measured. The GLMM model fitted well to our data, according to the Hosmer-Lemeshow test performed $\left(\chi^{2}=6.653\right.$, df $=$ $8, \mathrm{P}=0.575)$. Also, the composition of the accompanying plant species in sampling points with and without $P$. coerulea presence was significantly different (ANOSIM R $=0.345 ; \mathrm{P}=0.001)$, as there are only a few species that occur altogether with $P$. coerulea (Cistanthe grandiflora (Lindl.) Schltdl. (Montiaceae), Gamochaeta stachydifolia (Lam.) Cabrera (Asteraceae), Hypochaeris thrincioides (J. Rémy) Reiche (Asteraceae), Leucheria glandulosa D. Don

TABLE 1. Effects of abiotic variables on Puya coerulea presence after a GLMM model with binomial error distribution. / Efecto de las variables abióticas en la presencia de Puya coerulea según un modelo GLMM con distribución de error binomial.

\begin{tabular}{lcccc}
\hline & Estimate & StD. ERROR & z VALUE & P VAlUE \\
\hline Orientation $\left(^{\circ}\right)$ & 0.004 & 0.002 & 1.955 & 0.051 \\
Inclination $\left(^{\circ}\right)$ & 0.008 & 0.011 & 0.720 & 0.472 \\
$\mathrm{UV}$ radiation $\left(\mu \mathrm{W} / \mathrm{cm}^{2}\right)$ & 0.179 & 0.093 & 1.926 & 0.054 \\
\% Rock cover & 0.041 & 0.010 & 3.908 & $<0.001$ \\
\hline
\end{tabular}

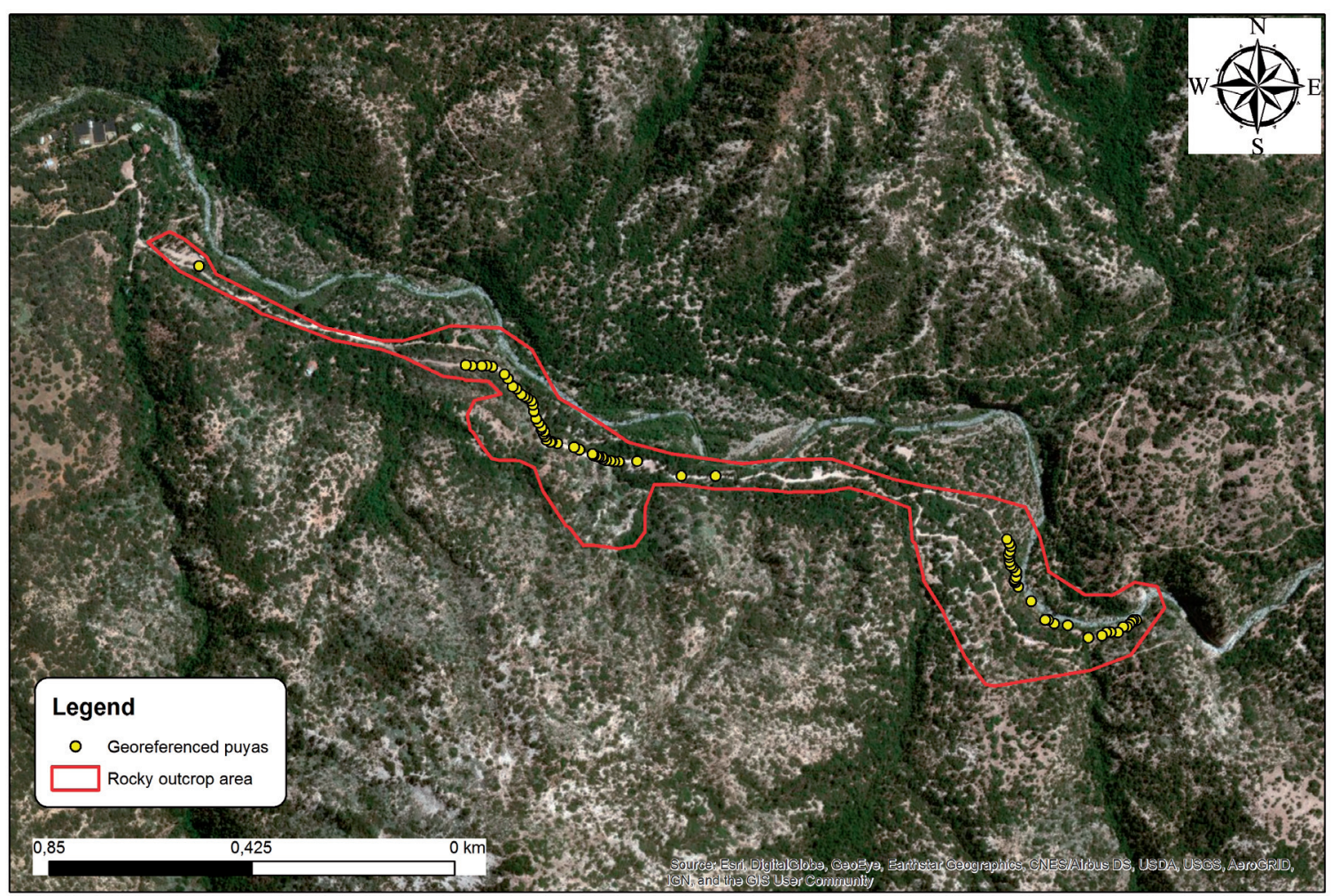

FIgURE 1. Distribution map of the georeferenced Puya coerulea clusters (yellow dots) at the Río Clarillo National Reserve. Suitable habitat (i.e., rocky outcrops) area is denoted with a red line. / Mapa de distribución de grupos de Puya coerulea georreferenciados (puntos amarillos) en la Reserva Nacional Río Clarillo. El área de hábitat apropiado (i.e., afloramientos rocosos) está delimitada por la línea roja. 
(Asteraceae)), which are able to coexist with $P$. coerulea as they have similar ecological strategies. We found two large clusters of $P$. coerulea along the suitable habitat area (Fig. 1 ), showing a non-random spatial distribution. These results are corroborated by the point-pattern analysis conducted, which show a greater aggregation than expected by chance between 5 and $20 \mathrm{~m}$ (Fig. 2).

Steep slopes and rocky outcrops are rarely colonized by woody species (i.e., trees and shrubs), leaving open colonization opportunities for herbaceous plant species (Callaway \& Walker 1997). This could be the case of $P$. coerulea, being favored by adaptations to colonize and thrive in habitats that many other plant species cannot use. This is confirmed by the scarce accompanying flora co-occurring with $P$. coerulea at the rocky outcrops. Also, we might expect $P$. coerulea to present some photosynthetic adaptations for overcome water stress conditions (Jabaily \& Sytsma 2010). In this sense, the entire subgenus Puyopsis (to which $P$. coerulea belongs) presents only C3-type photosynthesis, whereas many bromeliads present a C3-CAM flexible strategy to deal with arid conditions (Rundel \& Dillon 1998). Comparing P. coerulea to one of the most studied species of the Puya genus, P. raimondii Harms (Jabaily \& Sytsma 2010), it is possible that $P$. coerulea inhabits rocky outcrops because they provide microhabitat conditions with soils rich in organic matter, adequate humidity, aeration and radiation that provide protection to the strong temperature oscillations during the germination and sapling emergence stages (Vadillo \& Suni 2006). Another non-mutually exclusive explanation is the adaptation to these particular conditions to reduce inter-specific competition with other species that are unable to tolerate water shortage stress as Puya species do.

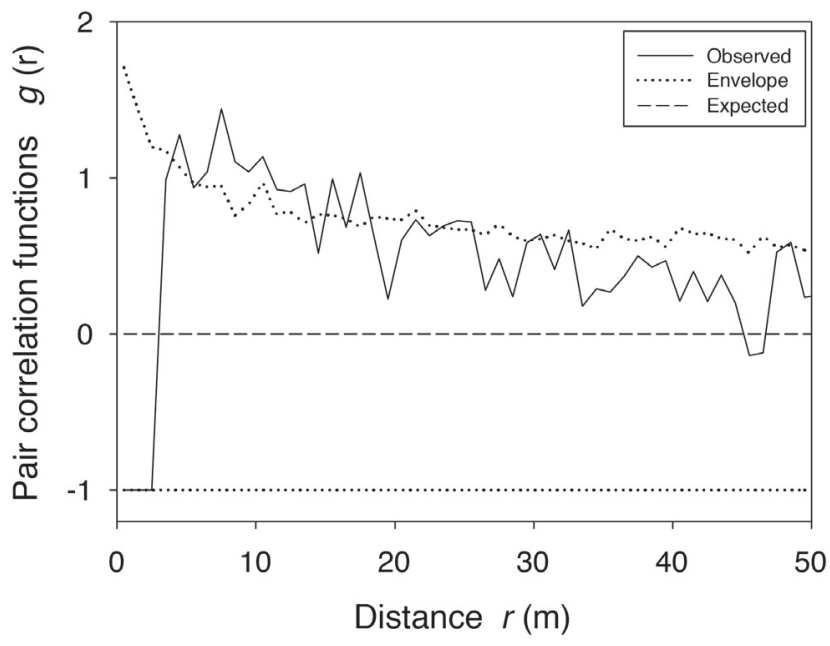

FIGURE 2. Spatial aggregation pattern according to the $g(r)$ function for the mapped Puya coerulea clusters. / Función g(r) de agregación espacial calculada para las agrupaciones de Puya coerulea mapeadas.
Puya coerulea is an important species of the Andean ecosystem, confined to the Coastal Range (Zizka et al. 2013). Therefore, we may expect that the distribution of this species responds not only to rock cover but also to geological features of these rocks. Further, intraspecific spatial aggregation in plant individuals can be considered as a process dependent on the dispersion of propagules, vegetative reproduction (clonal growth) and environmental patchiness on those abiotic factors that influencing plant reproduction and establishment (Stoll \& Prati 2001, Tirado \& Pugnaire 2003, Syphard \& Franklin 2004). Puya coerulea have very small elliptical seeds, which could be useful to be mobilized via anemocoria (Varadarajan 1990), being a fairly conserved trait within the Puya genus. This type of dispersal allows seeds to travel long distances, increasing colonization capabilities. However, limiting to the framework of observations made for $P$. coerulea it is possible that the effectiveness of this dispersal mechanism is affected by the substrate in which this species grows, certainly the seeds could be dispersed to distant sites, but few of them will reach suitable sites to germinate (Chesson 1991). Based on this, already established individuals may be skewing seed rain to suitable areas with high survival probabilities, potentially creating a positive feedback on the patchy spatial distribution pattern, increasing spatial aggregation over time.

\section{ACKNOWLEDGMENTS}

Valentina Riffo and Eduardo Pizarro collaborated with data collection and plant taxonomy. We thank C. Botto-Mahan for the field equipment and M. Murúa for her comments on the manuscript. We thank CONAF for authorizing data collection at the Río Clarillo National Reserve. FEF was supported by FONDECYT project 11160152 .

\section{REFERENCES}

Callaway, R.M., Walker, L.R. 1997. Competition and facilitation: A synthetic approach to interactions in plant communities. Ecology 78(7): 1958-1965.

Chesson, P. 1991. A need for niches? Trends in Ecology \& Evolution 6(1): 26-28.

Clarke, K.R. 1993. Nonparametric multivariate analyses of changes in community structure. Australian Journal of Ecology 18: 117-143.

Jabaily, R.S., Sytsma, K.J. 2010. Phylogenetics of Puya (Bromeliaceae): placement, major lineages, and evolution of Chilean species. American Journal of Botany 97(2): 337-356.

Nathan, R., Muller-Landau, H.C. 2000. Spatial patterns of seed dispersal, their determinants and consequences for recruitment. Trends in Ecology \& Evolution 15(7): 278285. 
R Core Development Team. 2018. R: A language and environment for statistical computing. R Foundation for Statistical Computing, Vienna, Austria.

Rundel, P.W., Dillon, M.O. 1998. Ecological patterns in the Bromeliaceae of the lomas formations of Coastal Chile and Peru. Plant Systematics and Evolution 212(3): 261278.

SмIth, L.B. 1970. Notes on Bromeliaceae XXX. Phytologia 19: 281-291.

Smith, L.B., Downs, R.J. 1974. Pitcairnioideae (Bromeliaceae). Flora Neotropica Monograph 14 (1): 1-660.

Stoll, P., Prati, D. 2001. Intraspecific aggregation alters competitive interactions in experimental plant communities. Ecology 82(2): 319-327.

Syphard, A.D., Franklin, J. 2004. Spatial aggregation effects on the simulation of landscape pattern and ecological processes in southern California plant communities. Ecological Modelling 180(1): 21-40.

Tirado, R., Pugnaire, F.I. 2003. Shrub spatial aggregation and consequences for reproductive success. Oecologia 136(2): 296-301.
Vadillo, G., Suni, M. 2006. Evaluación de sustratos para el establecimiento en laboratorio de plántulas de Puya raimondii Harms (Bromeliaceae). Revista Peruana de Biología 13(1): 139-141.

VARADARAJAN, G.S. 1990. Patterns of geographic distribution and their implications on the phylogeny of Puya (Bromeliaceae). Journal of the Arnold Arboretum 7(4): 527-552.

Wiegand, T., Moloney, K.A. 2004. Rings, circles, and nullmodels for point pattern analysis in ecology. Oikos 104(2): 209-229.

Wiegand, T., Moloney, K.A. 2014. Handbook of spatial pointpattern analysis in ecology CRC Press, Boca Raton, FL. $510 \mathrm{pp}$.

Zizka, G., Schneider, J.V., Schulte, K., NovoA, P. 2013. Taxonomic revision of the Chilean Puya species (Puyoideae, Bromeliaceae), with special notes on the Puya alpestris-Puya berteroniana species complex. Brittonia 65(4): 387-407.

Zuur, A.F., Ieno, E.N., Walker, N.J., Saveliev, A.A., Smith, G.M. 2009. Mixed effects models and extensions in ecology with R. Springer, New York. 549 pp.

Recibido: 14.09 .2018

Aceptado: 24.01.2019 